\title{
Aerosol mass and black carbon concentrations, a two year record at NCO-P (5079 m, Southern Himalayas)
}

\author{
A. Marinoni ${ }^{1}$, P. Cristofanelli ${ }^{1}$, P. Laj $^{2}$, R. Duchi ${ }^{1}$, F. Calzolari ${ }^{1}$, S. Decesari ${ }^{1}$, K. Sellegri ${ }^{3}$, E. Vuillermoz ${ }^{4}$, \\ G. P. Verza ${ }^{4}$, P. Villani ${ }^{2}$, and P. Bonasoni ${ }^{1,4}$ \\ ${ }^{1}$ CNR -ISAC- Institute for Atmospheric Sciences and Climate, Bologna, Italy \\ ${ }^{2}$ Laboratoire de Glaciologie et Géophysique de l'Environnement, CNRS-University of Grenoble, Grenoble, France \\ ${ }^{3}$ Laboratoire de Météorologie Physique, CNRS-University of Clermont Ferrand, Clermont-Ferrand, France \\ ${ }^{4}$ Ev-K2-CNR Committee, Bergamo, Italy
}

Received: 16 March 2010 - Published in Atmos. Chem. Phys. Discuss.: 31 March 2010

Revised: 8 July 2010 - Accepted: 10 August 2010 - Published: 10 September 2010

\begin{abstract}
Aerosol mass and the absorbing fraction are important variables, needed to constrain the role of atmospheric particles in the Earth radiation budget, both directly and indirectly through $\mathrm{CCN}$ activation. In particular, their monitoring in remote areas and mountain sites is essential for determining source regions, elucidating the mechanisms of long range transport of anthropogenic pollutants, and validating regional and global models. Since March 2006, aerosol mass and black carbon concentration have been monitored at the Nepal Climate Observatory-Pyramid, a permanent high-altitude research station located in the Khumbu valley at $5079 \mathrm{~m}$ a.s.l. below Mt. Everest. The first twoyear averages of $\mathrm{PM}_{1}$ and $\mathrm{PM}_{1-10}$ mass were $1.94 \mu \mathrm{g} \mathrm{m}^{-3}$ and $1.88 \mathrm{\mu g} \mathrm{m}^{-3}$, with standard deviations of $3.90 \mu \mathrm{g} \mathrm{m}^{-3}$ and $4.45 \mu \mathrm{g} \mathrm{m}^{-3}$, respectively, while the black carbon concentration average is $160.5 \mathrm{ng} \mathrm{m}^{-3}$, with a standard deviation of $296.1 \mathrm{ng} \mathrm{m}^{-3}$. Both aerosol mass and black carbon show well defined annual cycles, with a maximum during the premonsoon season and a minimum during the monsoon. They also display a typical diurnal cycle during all the seasons, with the lowest particle concentration recorded during the night, and a considerable increase during the afternoon, revealing the major role played by thermal winds in influencing the behaviour of atmospheric compounds over the high Himalayas. The aerosol concentration is subject to high variability: in fact, as well as frequent "background conditions" (55\% of the time) when BC concentrations are mainly below $100 \mathrm{ng} \mathrm{m}^{-3}$, concentrations up to $5 \mu \mathrm{g} \mathrm{m}^{-3}$ are reached during some episodes (a few days every year) in the premonsoon seasons. The variability of PM and BC is the result
\end{abstract}

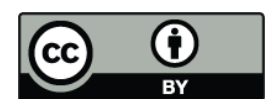

Correspondence to: A. Marinoni (a.marinoni@isac.cnr.it) of both short-term changes due to thermal wind development in the valley, and long-range transport/synoptic circulation. At NCO-P, higher concentrations of $\mathrm{PM}_{1}$ and $\mathrm{BC}$ are mostly associated with regional circulation and westerly air masses from the Middle East, while the strongest contributions of mineral dust arrive from the Middle East and regional circulation, with a special contribution from North Africa and South-West Arabian Peninsula in post-monsoon and winter season.

\section{Introduction}

Atmospheric aerosols particles are the focus of increasing attention, due to their role in many atmospheric processes, in particular those involved in the Earth's radiative balance. The uncertainty linked to aerosol forcing is a major obstacle to the accurate prediction of future anthropogenic-induced climate changes (Forster et al., 2007). Aerosol radiative forcing depends either directly or indirectly on several intensive properties of particles, including mass concentration, presence of absorbing material in their composition and size distribution.

While the variability of aerosol mass (PM) concentration is well documented in urban and peri-urban areas due to air quality regulations, uneven global and regional coverage of PM observations remains a limitation for assessing global aerosol atmospheric loadings and source identification. Access to PM information is limited in many parts of the world, especially in remote regions and the free troposphere (Laj et al., 2009). In many studies on climate and air quality, knowledge of PM variability needs to be integrated with information on the main constituents of fine atmospheric aerosol,

Published by Copernicus Publications on behalf of the European Geosciences Union. 
inorganic ions, mineral dust, organic compounds and black carbon $(\mathrm{BC})$.

Aerosol particles may be transported over long distances and reach remote areas, especially in dry climates, because of the slow rate of their removal from the atmosphere in the absence of precipitation. Long range transport of aerosol to clean background areas may have a substantial effect on regional climate change, but also on public health issues (Chung and Seinfeld, 2005; Kanakidou et al., 2005; Sun and Ariya, 2006).

Ubiquitous throughout the atmosphere, $\mathrm{BC}$ is present in low levels in remote areas, like the South Pole (Andreae et al., 1984; Hansen et al., 1984, 1988) and Manua Loa (Bodhaine, 1995) but higher concentrations $\left(1-30 \mu \mathrm{g} \mathrm{m}^{-3}\right)$ are observed near sources, in urban areas and biomass burning regions (Cachier at al., 1986; Ruellan et al., 1999). Jacobson (2001) pointed out that the magnitude of direct radiative forcing due to $\mathrm{BC}$ may exceed that due to methane, thereby making it one of the main species contributing to global warming. INDOEX measurements have reported $14 \%$ of $\mathrm{BC}$ in fine aerosol dry mass in the marine boundary layer (Lelieveld et al., 2001; Ramanathan et al., 2001). Apportionment of BC is a major concern when modelling aerosol radiative properties. Such estimates are extremely rare for Indian locations, where surprisingly high pollution levels have also been observed over the surrounding ocean. The Indian subcontinent is a region where atmospheric pollution is rapidly on the rise, causing extensive air quality degradation, with local, regional and global implications, including an impact on the oxidizing power of the atmosphere. (Lelieveld 2001). In fact, recently surface and satellite observations have pointed to the persistence of so-called "Brown Clouds", i.e. wide polluted tropospheric layers characterised by anthropogenic aerosol optical depth (AOD) greater than 0.3 and absorbing AOD greater than 0.03 (Ramanathan et al., 2007)

A knowledge of aerosol mass and black carbon concentrations in remote regions is therefore necessary to determine emission sources, quantify long range transport and validate both regional and global models. High-elevation sites are well-suited for documenting components of the free troposphere, in order to characterize its typical background conditions and investigate the influence of human activity on its composition. For these reasons, aerosol mass and black carbon concentrations have been monitored at the Nepal Climate Observatory-Pyramid (NCO-P) since March 2006 in the framework of ABC (Atmospheric Brown Clouds) UNEP and SHARE (Station at High Altitude for Environmental Research) Ev-K2-CNR projects. Located in the Khumbu valley at $5079 \mathrm{~m}$ a.s.l. below Mt. Everest, NCO-P is one of the very few monitoring stations in this area. The two-year continuous record (March 2006-February 2008) of fine and coarse aerosol mass concentrations and black carbon content completes the very rare records published for this area (Shrestha et al., 2000; Carrico et al., 2003).
The present paper describes observations of PMs and $\mathrm{BC}$ at the site and discusses factors influencing aerosol diurnal and seasonal variability. In particular, the role of valley breezes and synoptic circulation on the aerosol transport up to such high altitude is also investigated. Because NCO-P is located within the area of the Himalayan glaciers, a knowledge of concentrations and sources of BC, the most efficient light-absorber in atmosphere and snow, is a key step towards a better assessment of anthropogenic pressures on snow-pack and glacier dynamics.

With the presentation of an unique data set referring to aerosol mass and black carbon observations carried out in a crucial area that plays a key role in climate change, the main objectives of this paper are to present and discuss the principal factors influencing the aerosol variability, in order to provide important information for the characterization of tropospheric background conditions and precious input to improve the performance of climate and atmospheric chemistry models at different scales.

\section{Measurement site and experimental set up}

A complete description of the NCO-P station (Nepal, $27.95 \mathrm{~N}, 86.82 \mathrm{E}, 5079 \mathrm{~m}$ a.s.l.) is provided in Bonasoni et al. (2008) and Bonasoni et al. (2010). At NCO-P, the seasonal variation of atmospheric conditions is influenced both by the local mountain wind system (with a strong diurnal valley wind and a weaker mountain night-time breeze), and by the large-scale Asian monsoon circulation. In particular, besides determining the seasonal variations of meteorological parameters, the annual variations of the main synoptic circulation can also modulate the diurnal cycles characterizing the local mountain weather regime (Bonasoni et al., 2010).

The instrumentation includes a Multi-Angle Absorption Photometer (MAAP 5012, Thermo Electron Corporation) and an optical particle counter (GRIMM\#190), both devices sampling air from a TSP (Total Suspended Particle) head. On-site technical support is provided year-round by the EvK2-CNR Committee, while a field campaign on site is organized once a year for extra maintenance work, instrument calibration, and possible technical upgrades. The energy required for NCO-P operations is provided by 98 photovoltaic cells and 120 battery storage, other than those supplied by Pyramid panels and cells. A diesel generator (located $100 \mathrm{~m}$ below NCO-P) is used to supply electricity in the event of solar-energy shortage, although this occurs rarely (less than $6 \%$ of total period), and tests have been performed to insure that no contamination of NCO-P measurements occurs due to diesel use.

PM is measured using the optical particle counter (OPC), which measures the size distributions for particle with diameters greater than 0.25 up to $32 \mu \mathrm{m}$ by means of $90^{\circ}$ laser light scattering. The optical diameters determined by the OPC (classified in 31 bins) are converted into geometric diameters 
assuming spherical particles. According to the manufacturer, the accuracy of the Grimm 190 OPC in particle counting is $\pm 2 \%$ over the entire measurement size range. The OPC particle sizing is based on a calibration with latex spheres ( $1 \mu \mathrm{m}$ Duke Scientific Corp.) performed by the manufacturer prior to starting measurements at NCO-P. Additional calibration was performed in February 2008 using latex spheres (400 nm Duke Scientific Corp.), showing a slight, but acceptable, diameter underestimation of less than $5 \%$. To calculate the apparent particulate mass within the different size ranges $\left(\mathrm{PM}_{1}, \mathrm{PM}_{2.5}\right.$ and $\left.\mathrm{PM}_{10}\right)$, the particle density was chosen by the manufacturer during the first calibration using Micro Dolomit DR80 (Basserman \& Co). Particles smaller than $0.3 \mu \mathrm{m}$ were assumed not to significantly contribute to the particulate mass: the error associated to PM determination was lower than $2 \%$ in each size fraction. The OPC was placed in the NCO-P shelter with temperature almost constant (between 20 and $25^{\circ} \mathrm{C}$ ), at least $10^{\circ} \mathrm{C}$ higher with respect to the external one, thanks to heating produced by the instrument energy consumption. The particles were thus measured at a relative humidity slightly lower than ambient RH. However above $70 \%$ RH (measured in the sample head), a dehumidification system becomes active, removing humidity over a Nafion $₫$ membrane-tube from the sample pipe to avoid condensation during measurement. The detection limit was determined as $3 \sigma$ of $12 \mathrm{~h}$ of measurement with an absolute filter, corresponding to $5.8 \mathrm{p} \mathrm{L}^{-1}$, i.e. equivalent to $0.06 \mu \mathrm{g} \mathrm{m}^{-3}$.

The measurement of the aerosol absorption coefficient was obtained by MAAP: it measures the transmission and the back scattering of a light beam (Petzold and Schonlinner, 2004) incident on a fibre filter where aerosol particles are deposited by sampling flow. As determined during an intercomparison experiment (March 2007) at the Leibniz Institute for Tropospheric Research (Leipzig, Germany), the wavelength of the light source employed in the MAAP is $635 \mathrm{~nm}$ (T. Müller, personal communication, 2008). The reduction of light transmission, multiple reflection intensities, air sample volume are continuously integrated over the sample run period to provide real-time data output of the particle light absorption coefficient $\sigma_{\text {abs }}$ and thus black carbon concentration.

In the visible spectral range, black carbon is the most efficient light-absorbing aerosol species (Horvarth, 1993). The relationship between the aerosol absorption coefficient $\sigma_{\mathrm{abs}}$ $\left(\mathrm{m}^{-1}\right)$ and the corresponding black carbon mass concentration $\mathrm{BC}\left(\mathrm{ng} \mathrm{m}^{-3}\right)$ is established by a mass absorption efficiency $\sigma_{\mathrm{me}}, \mathrm{BC}\left(\mathrm{m}^{2} \mathrm{~g}^{-1}\right)$ via the relationship:

$\mathrm{BC}=\frac{\sigma_{\mathrm{abs}}}{\sigma_{\mathrm{me}, \mathrm{BC}}}$

where $\sigma_{\mathrm{me}}, \mathrm{BC}$ and $\sigma_{\mathrm{abs}}$ are wavelength dependent. $\sigma_{\mathrm{me}}, \mathrm{BC}$ depends on the type of aerosol, the ageing and the size of the BC particles (Liousse et al., 1993). A thermo-optical method (OC/EC analyzer, Sunset laboratory Inc.) was used to de- termine the mass absorption efficiency $\left(\sigma_{\mathrm{me}}, \mathrm{BC}\right)$, assuming that elemental carbon (EC) is equivalent to BC (details of analyses in Decesari et al., 2009). Here, the value of $\sigma_{\text {me }}$, BC adopted was $6.5 \mathrm{~m}^{2} \mathrm{~g}^{-1}$, as recommended by Petzold et al. (2002) and set by default on MAAPs. The very good correlation between $\mathrm{EC}$ and equivalent $\mathrm{BC}\left(\mathrm{R}^{2}=0.94\right)$, obtained by totally independent methods confirms the fact that, despite the presence of high levels of dust (Duchi et al., 2010), MAAP absorption measurements are primarily influenced by $\mathrm{BC}$. This justifies the use, in the remaining part of the paper, of the term "equivalent BC" for MAAP measurements.

In order to check the MAAP noise and detection limit, a 12 $\mathrm{h}$ measurement with an absolute filter was performed during the calibration campaign in February 2008, together with the calibration of flow and temperature-pressure sensors. The detection limit ( $3 \sigma$ of blank measurements) was calculated as $11 \mathrm{ng} \mathrm{m}^{-3}$, with an integration time of a $30 \mathrm{~min}$ basis.

Both instruments worked continuously without major failures, and interruptions were extremely rare and of limited duration. Measurements (available in real-time at the web address http://evk2.isac.cnr.it/realtime.html) were performed with a time resolution of $1 \mathrm{~min}$ and data were averaged to a common time base of $30 \mathrm{~min}$. All measurements presented in this study refer to STP conditions (1 atm and $0{ }^{\circ} \mathrm{C}$ ) and Nepal Standard Time (NST, UTC+5.45).

\section{Results and discussion}

\subsection{Variability of PMs and BC concentrations}

Mass concentrations of accumulation $(0.25-1 \mu \mathrm{m})$ and coarse $(1-10 \mu \mathrm{m})$ particulate matter calculated by OPC, as well as equivalent BC mass concentration, are reported in Fig. 1, while their seasonal statistics are given in Table 1. The accumulation fraction mass will be referred hereinafter as $\mathrm{PM}_{1}$, since the sum of chemical species analysed on $\mathrm{PM}_{1}$ filters (Decesari et al., 2009) accounts on average for $91 \%$ of the accumulation fraction mass calculated by OPC: the fraction of particles smaller than $0.25 \mu \mathrm{m}$ (not detected by OPC) are thus assumed as negligible.

The two-year average of $\mathrm{PM}_{1}$ and $\mathrm{PM}_{1-10}$ mass were $1.94 \mu \mathrm{g} \mathrm{m}^{-3}$ and $1.88 \mu \mathrm{g} \mathrm{m}^{-3}$, with a standard deviation of $3.90 \mu \mathrm{g} \mathrm{m}^{-3}$ and $4.45 \mu \mathrm{g} \mathrm{m}^{-3}$, respectively. Thus, the coarse fraction accounts for half of the aerosol mass measured by OPC, with a greater variability with respect to the accumulation fraction. The black carbon concentration averaged over two years of measurements was $160.5 \mathrm{ng} \mathrm{m}^{-3}$, with a standard deviation of $296.1 \mathrm{ng} \mathrm{m}^{-3}$, accounting for $10.8 \%$ of $\mathrm{PM}_{1}$ on average.

\subsubsection{Seasonal variations of PMs and BC}

Both fine and coarse fractions of aerosol mass exhibit a well defined diurnal cycle, as well as significant annual variations. In fact, as shown in Figs. 1 and 2, large mass concentrations 
Table 1. Seasonal average and standard deviation for $\mathrm{BC}, \mathrm{PM}_{1}, \mathrm{PM}_{1-10}$ (30-min averaged values). In brackets, the annual average values for 2006 (Y06) and 2007 (Y07) are also reported. $N$ represents the number of averaged values.

\begin{tabular}{|c|c|c|c|c|}
\hline Seasons & $\mathrm{PM}_{1}\left(\mu \mathrm{g} \mathrm{m}^{-3}\right)$ & $\mathrm{PM}_{1-10}\left(\mu \mathrm{g} \mathrm{m}^{-3}\right)$ & $\mathrm{BC}\left(\mathrm{ng} \mathrm{m}^{-3}\right)$ & $\mathrm{BC} / \mathrm{PM}_{1}(\%)$ \\
\hline \multirow[t]{3}{*}{ Pre-monsoon } & $3.9 \pm 5.5$ & $3.4 \pm 6.7$ & $320 \pm 469$ & $10.5 \pm 28.0$ \\
\hline & (Y06: 4.4; Y07: 3.5) & (Y06: 2.5; Y07: 3.6) & (Y06: 376; Y07: 279) & (Y06: 9.0; Y07: 11.7) \\
\hline & $N=10045$ & $N=10045$ & $N=10237$ & $N=9844$ \\
\hline \multirow[t]{3}{*}{ Monsoon } & $0.6 \pm 1.1$ & $1.1 \pm 2.7$ & $56 \pm 75$ & $40.0 \pm 141$ \\
\hline & (Y06: 0.8; Y07: 0.3) & (Y06: 1.4; Y07: 0.6) & (Y06: 85; Y07:41) & (Y06: 6.8; Y07: 71.8) \\
\hline & $N=10653$ & $N=10653$ & $N=9406$ & $N=6472$ \\
\hline \multirow[t]{3}{*}{ Post-monsoon } & $1.5 \pm 1.4$ & $0.5 \pm 1.4$ & $137 \pm 126$ & $10.0 \pm 5.0$ \\
\hline & (Y06: 1.5; Y07: 1.5) & (Y06: 0.5; Y07: 0.6) & (Y06: 132; Y07: 144) & (Y06: 8.5; Y07: 12.4) \\
\hline & $N=4189$ & $N=4189$ & $N=4144$ & $N=4078$ \\
\hline \multirow[t]{3}{*}{ Winter } & $1.4 \pm 3.6$ & $1.6 \pm 4.3$ & $125 \pm 147$ & $12.4 \pm 7.4$ \\
\hline & (Y06: 1.0; Y07: 2.3) & (Y06: 1.4; Y07: 2.2) & (Y06: 124; Y07: 126) & (Y06: 12.8;Y07: 11.7) \\
\hline & $N=4777$ & $N=4777$ & $N=7539$ & $N=4417$ \\
\hline
\end{tabular}

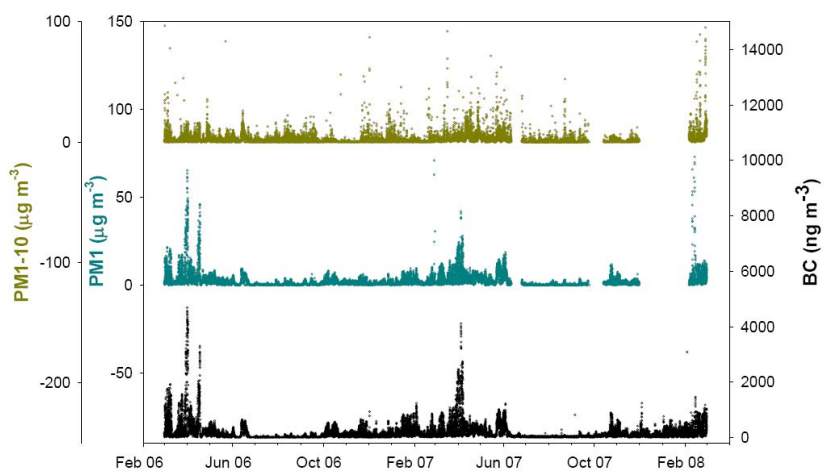

Fig. 1. Time series of 30-min averaged $\mathrm{BC}$ (black), $\mathrm{PM}_{1}$ (cyan) and $\mathrm{PM}_{1-10}$ (brown) at NCO-P.

occur during the pre-monsoon season, while the minima appear during the monsoon season (prolonged to the post monsoon for the coarse fraction). $\mathrm{PM}_{1}$ shows a more enhanced annual variation than $\mathrm{PM}_{1-10}$ : the pre-monsoon average is larger by a factor of 5.6 with respect to the monsoon mean value, while the coarse fraction mass (characterised by a larger year-to-year variation) shows a pre-monsoon average value larger than the monsoon average by a factor of 3.0. The year 2007 was characterized by a more peaked variation, especially for coarse fraction. The ratio between the seasonal maximum and minimum of aerosol mass in 2007 was 11.4 for the coarse fraction and 5.6 for the fine fraction, while in 2006 they were 1.7 and 5.7, respectively. The origin of the inter-annual difference may be associated with the interannual variations in meteorological and dynamic conditions already observed in this area, such as the Tropospheric Biennial Oscillation, leading to warmer and wetter even years than odd years (Bertolani et al., 2000; Pillai and Mohankumar, 2007).
The annual behaviour of $\mathrm{BC}$ concentration is very similar to the $\mathrm{PM}_{1}$ annual cycle, with a maximum during the pre-monsoon season, a minimum during the monsoon and a similar cycle amplitude (pre-monsoon average value is larger than the monsoon value by a factor of 5.0 over the 2 years, 4.5 in 2006 and 6.6 in 2007). A weak inter-annual variation characterised the BC behaviour at NCO-P. In fact, except for the post-monsoon and winter season, the year 2006 appears slightly more "polluted" than 2007 (see Table 1 and Fig. 2). The very high $\mathrm{BC}$ standard deviation reflects the high variability of BC concentrations: frequent "background conditions" ( $55 \%$ of the time), with concentrations mainly below $100 \mathrm{ng} \mathrm{m}^{-3}$ are observed, while during some episodes (a few days every year) in pre-monsoon seasons, BC concentrations up to $5 \mathrm{\mu g} \mathrm{m}^{-3}$ (30 min averaged values) are reached (Fig. 1).

The aerosol mass and BC seasonality observed at NCO-P is similar to the variations observed at other Indian sites, with lower values during the monsoon season, mostly due to wet scavenging, and larger ones in the winter and pre-monsoon periods (Chandra Mouli et al., 2006; Ganguly et al., 2006). In the Indogangetic plain, at Gadanki station (India, $375 \mathrm{~m}$ a.s.1., $13.5^{\circ} \mathrm{N}, 79.2^{\circ} \mathrm{E}$ ), Krishnan and Kunhikrishnan (2004) observed that the atmospheric boundary layer height was maximum during the pre-monsoon period, and minimum during the winter months. It can therefore be supposed that the high pre-monsoon values observed at NCO-P are influenced by the larger vertical extension of the regional $\mathrm{PBL}$ (indicative of the $\mathrm{ABC}$ vertical extension), which together with the valley breezes, can favour the transport of regional pollution up to the $5000 \mathrm{~m}$ a.s.l. of NCO-P.

\section{Variations of $\mathbf{B C} / \mathbf{P M}_{1}$}

The contribution of BC to fine aerosol mass at NCO-P was found to be $10.8 \%$, with a very large variability (standard 

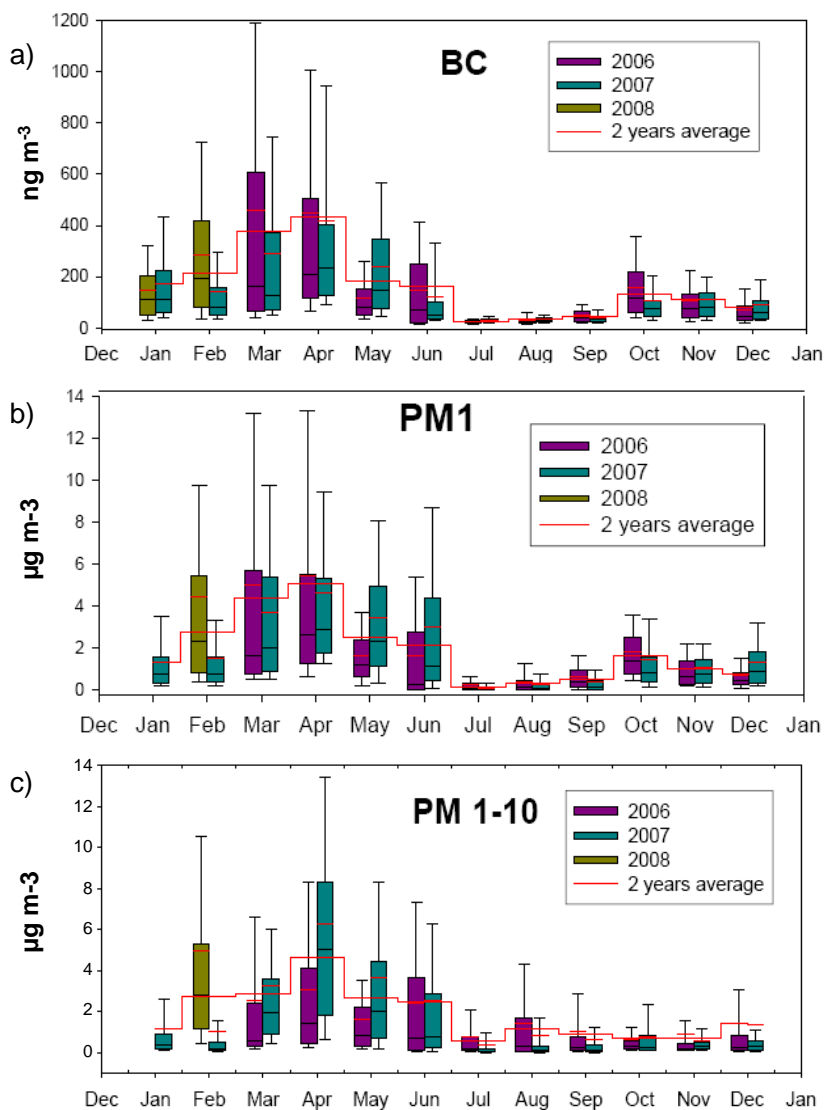

Fig. 2. Monthly averages (black line within the boxes), medians (red line within the boxes) and percentiles (10-25-75-90, boxes and whiskers) of 30-min $\mathrm{PM}_{1}$ (a), $\mathrm{PM}_{1-10}$ (b) and $\mathrm{BC}$ (c) at NCO$\mathrm{P}$. The continuous red lines represent the 2 year averaged monthly behaviours.

deviation: 9.5\%). As shown in Fig. 3, the $\mathrm{BC} / \mathrm{PM}_{1}$ ratio shows a maximum contribution of carbonaceous absorbing material to the fine particulate matter during the monsoon season (about $18 \%$ in July-August), while the minimum values characterizes the pre-monsoon season (less than $9 \%$ in April-May). This is plausibly due to a preferential scavenging by monsoon precipitation of the inorganic fraction of aerosol with respect to the less hygroscopic black carbon (Sellegri et al., 2003). Moreover, this may also be addressed to the influence of local BC emissions due to incomplete combustion processes from domestic heating and cooking activities. In fact, during the monsoon season highly efficient scavenging processes clean air masses originating over Indian plains, while local/regional sources, even when weak, could influence the background composition of Himalayas atmosphere. Even though BC contributes only a few percent to the total aerosol mass, it produces significant radiative effects. The apportionment of $\mathrm{BC}$ is therefore very important in assessing the aerosol radiative properties, as confirmed by Marcq et al. (2010) who report lower single scattering albedo values during the monsoon season.

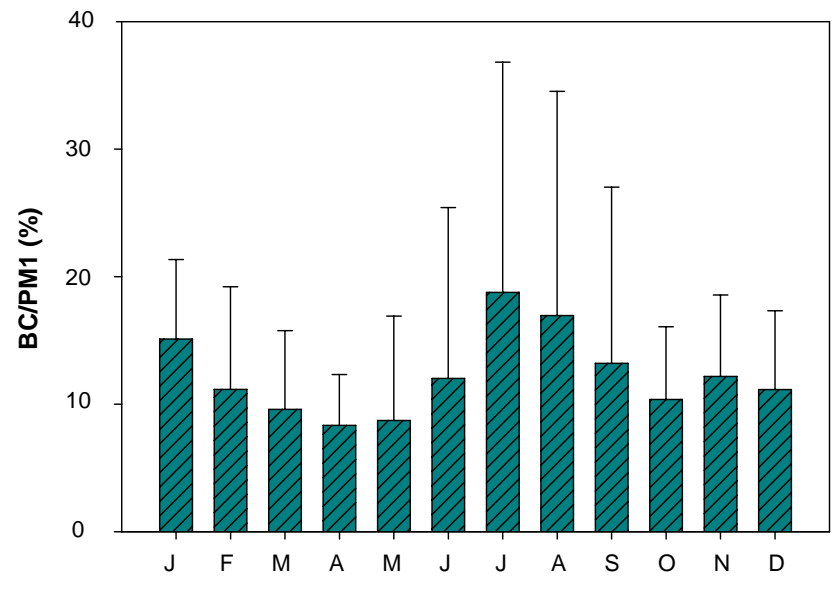

Fig. 3. Annual variation of $\mathrm{BC}$ to $\mathrm{PM}_{1}$ mass fraction (2 year average; error bars represent the standard deviation).

The $\mathrm{BC} / \mathrm{PM}_{1}$ ratio observed at NCO-P is higher than values observed at lower altitude Himalayan sites in India. In fact, Saha et al. (2005) found a winter average value of $\sim 5 \%$, at Manora Peak $\left(29.4^{\circ} \mathrm{N} ; 79.5^{\circ} \mathrm{E} ; 1951 \mathrm{~m}\right.$ a.s.l., India) during winter 2004, while Hyvärinen et al. (2009) pointed out a $\sim 4 \%$ average $\mathrm{BC} / \mathrm{PM}_{2.5}$ ratio at Mukteshwar $\left(29.4^{\circ} \mathrm{N}\right.$; $79.6^{\circ} \mathrm{E}, 2180 \mathrm{~m}$ a.s.1., India). This indicates the existence of significant differences in aerosol composition along $\mathrm{Hi}-$ malayas ridge. In fact, for NCO-P, the $\mathrm{BC} / \mathrm{PM}_{1}$ is similar to those observed within brown clouds over Indian Ocean and populated urban areas. Moreover the $\mathrm{BC} / \mathrm{PM}_{1}$ ratio seems to be higher with cleaner atmospheric conditions, suggesting a preferential removing of non-BC aerosol. INDOEX measurements (January to March 1999) reported surprisingly high pollution levels (comparable to urban air pollution in North America and Europe) over the entire northern Indian Ocean, with $14 \%$ of $\mathrm{BC}$ in fine aerosol dry mass in the marine boundary layer (Lelieveld et al., 2001; Ramanathan et al., 2001b). Novakov et al. (2000) found a BC content similar to the NCO-P one in the Indian Ocean haze, as high as $17 \%$ of the total fine particle mass. This very high fraction correlated very well with total carbon and sulphate, suggesting the predominantly primary nature of aerosol carbon and the significant influence of fossil fuel combustion sources. As reported by Babu and Moorthy (2002), BC/PM 1 values ranging from $\sim 3-4 \%$ (during monsoon) to $9 \%$ (during winter) were observed at Trivandrum $(\sim 1$ million inhabitants, South India). Except for the remote site of Mukteshwar (2180 m, North India), where on average only $4 \%$ of $\mathrm{PM}_{2.5}$ mass consisted of $\mathrm{BC}$, the ensemble of Asian observations shows values generally higher than the European continental background: Cozic et al. (2006) found a $\mathrm{BC}$ contribution to $\mathrm{PM}_{1}$ equal to $2.5 \%$ in summer and $4.7 \%$ in winter at the free troposphere station of Jungfraujoch (Switzerland, $3850 \mathrm{~m}$ a.s.l.), while Putaud et al. (2004) found a contribution in the range of $5-10 \%$ to $\mathrm{PM}_{2.5}$ at a European natural background sites. As indicated 

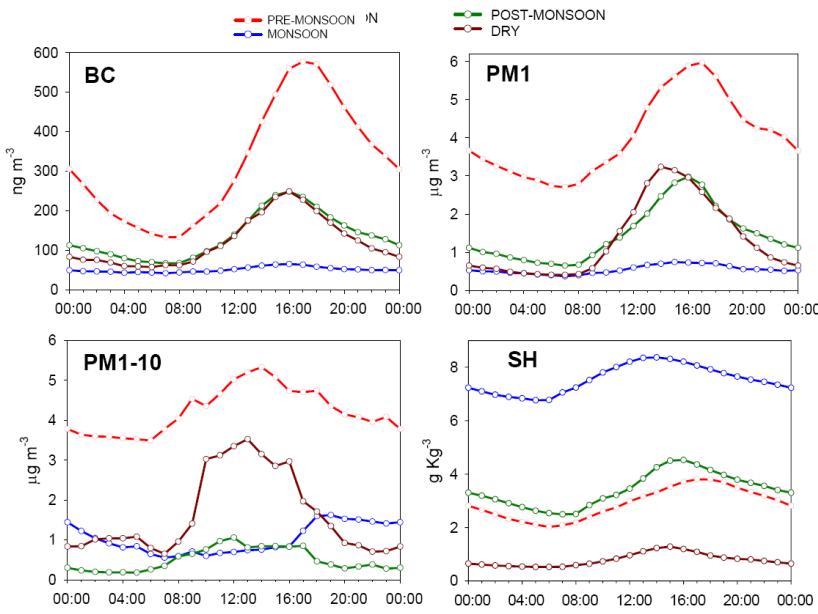

Fig. 4. 2-year seasonal diurnal variation of $\mathrm{BC}, \mathrm{PM}_{1}, \mathrm{PM}_{1-10}$ and specific humidity ( $\mathrm{SH}$ ) at NCO-P: pre-monsoon (red), monsoon (blue), post-monsoon (green) and winter (brown).

by Babu et al. (2004), the $\mathrm{BC} / \mathrm{PM}_{1}$ ratio is a key parameters to define the atmospheric forcing efficiency of aerosols. Thus, the high $\mathrm{BC} / \mathrm{PM}_{1}$ ratio observed at the NCO-P suggests that $\mathrm{BC}$ plays a major role in driving atmosphere energy budget over High Himalayas, as also indicated by Marcq et al. (2010).

\subsubsection{Diurnal variations}

The NCO-P average seasonal diurnal variations of $\mathrm{PM}_{1}$, $\mathrm{PM}_{1-10}$ and black carbon, together with specific humidity (SH), often used as a tracer of PBL-influenced air masses for mountain sites (e.g. Henne et al., 2008), are shown in Fig. 4. Alongside day-to-day variability, $\mathrm{PM}_{1}$ and black carbon also show a typical diurnal cycle in all the seasons with the lowest particle concentrations at night and a considerable increase during the afternoon. As shown by Venzac et al. (2008) and Bonasoni et al. (2010), such behaviours suggest an important influence of thermal winds in determining the variation of atmospheric compounds over the high Himalayas. Similar phenomena have been observed at many mountain stations in the European Alps (Baltensperger et al., 1997), Italian Apennines (Marinoni et al., 2008), Massif Central in France (Venzac et al., 2009), and Hawaii (Bodhaine, 1995). The maximum of pollutant ( $\mathrm{PM}_{1}$ and $\left.\mathrm{BC}\right)$ concentrations is reached between 16:00 and 18:00 NST during the pre-monsoon season and about one or two hours earlier in the other seasons, while the minimum appears between 06:00 and 08:00 NST in all the seasons, except for the winter one, when it is reached around 04:00 NST and persists longer.

It is interesting to note that the SH diurnal cycle shows the same behaviour as $\mathrm{BC}$ and $\mathrm{PM}_{1}$ variations, except in the monsoon season, when the $\mathrm{BC}$ and $\mathrm{PM}$ peaks and minima are delayed by about two hours with respect to $\mathrm{SH}$. Here, it is hypothesized that the early peak of SH in the monsoon season
Table 2. Diurnal cycle amplitudes of the typical day in different seasons for specific humidity $(\mathrm{SH})$, black carbon $(\mathrm{BC}), \mathrm{PM}_{1}$ and $\mathrm{PM}_{1-10}$. Amplitudes are expressed as the ratio between the highest and the lowest 30-min averaged values.

\begin{tabular}{lllll}
\hline Parameter & Pre-monsoon & Monsoon & Post-monsoon & Winter \\
\hline SH & 1.7 & 1.2 & 1.8 & 2.5 \\
BC & 4.8 & 1.4 & 3.5 & 3.8 \\
PPM $_{1}$ & 2.1 & 1.9 & 4.2 & 7.2 \\
PM $_{1-10}$ & 1.2 & 0.7 & 1.9 & 2.0 \\
\hline
\end{tabular}

is due to an additional water vapour source from evapotranspiration along the valley in central hours of the day, while outside the monsoon season, humidity reaches NCO-P simultaneously with pollutants from low levels of the Khumbu Valley and Pahar region.

Pollutants reaching the high altitude site, pumped up by thermal winds or transported by synoptic circulation, can be injected into the free troposphere, where they attain a longer life time, and/or accumulate in high residual layers. As shown in Table 2, the amplitude of the $\mathrm{BC}$ and $\mathrm{PM}_{1}$ diurnal cycle is very close to that of SH during the monsoon season, and higher in other seasons. Additionally, the nighttime $\mathrm{BC}$ contribution to the fine aerosol mass is, on average, between $2 \%$ and $10 \%$ higher than the day-time contribution. The higher BC fraction in night-time aerosol sampled at the station may reflect an ageing of the aerosol population; in fact the polymerisation of organic material in aerosol particles can lead to increasingly absorbing properties (Andreae and Gelenscer, 2006).

Following the approach of Baltensperger et al. (1997), the fraction of days showing a strong influence of valley-induced thermal convection was calculated, on the basis of the black carbon concentration. Applying this criterion a "strong" diurnal variation was found in $38 \%$ of all days $(55 \%$ in the pre-monsoon and only $7 \%$ in the monsoon season).

The most "polluted" days (characterized by a daily BC average larger than the 90th percentile) were characterized by a larger amplitude of pollutant diurnal variation: for the total average the 15:00-21:00 (NST) period shows a mean $\mathrm{BC}$ value 3.5 higher than the 03:00-09:00 period, while considering only days with a daily BC average over the 90th percentile (345 $\mathrm{ng} \mathrm{m}^{-3}$ ), the 15:00-21:00 period became 8.2 times higher than the 03:00-09:00. Nevertheless, among the "polluted" days, more than $30 \%$ showed limited amplitude of the diurnal cycle and therefore not classified as days with "strong" diurnal variation. The recirculation and transport of pollutants possibly stored in reservoir layers can partially explain the limited amplitude of the diurnal cycle. However, these findings seem to confirm that two main mechanisms are involved in the transport of pollutants to NCO-P: thermal winds, leading to an enhanced diurnal cycle, and synoptic circulation, which constrains and limits the thermal wind influence. 
Typical events with marked diurnal variations, with the highest concentration of $\mathrm{PM}_{1}$ (around $60 \mu \mathrm{g} \mathrm{m}^{-3}$ ) and $\mathrm{BC}$ (attaining $5 \mu \mathrm{g} \mathrm{m}^{-3}$ ), were recorded in March-April of both 2006 and 2007: the strongest of such events are recognizable also in 30-min averaged time series shown in Fig. 1 (i.e. 30-31 March, 1-3 and 15-17 April 2006, 30-31 March, 1 and 3-6 April 2007). Conversely, when the rise in pollution concentration shows a very limited diurnal cycle, it is most likely that the air mass is transported by synoptic circulation, which superimposes and masks locally originated thermal winds. A typical prolonged long range transport is recorded both in 2006 and 2007 in the monsoon onset period (12-22 June 2006 and 22 May-7 June 2007).

The aerosol coarse mass has a more irregular diurnal variation than $\mathrm{PM}_{1}$ and $\mathrm{BC}$, with daytime concentrations (10:0018:00 NST) higher than night-time ones in all seasons except for the monsoon. The diurnal peaks are not linked with the lifting of air masses by valley winds, but seem to be linked with wind strength, with a maximum at midday $(4-5 \mathrm{~h}$ before pollution maximum), suggesting a limited contribution from the local re-suspension of coarse particles. Furthermore the coarse mass variations are weaker than the seasonal and diurnal cycles of the fine fraction (see Table 2), while $\mathrm{PM}_{1-10}$ and the respective diurnal cycle amplitude are higher in the post monsoon and winter seasons, when the soil is drier (Fig. 4).

\subsubsection{Comparison with other sites}

At NCO-P, the two-year average of $\mathrm{PM}_{1}$ and $\mathrm{PM}_{1-10}$ mass were $1.94 \mu \mathrm{g} \mathrm{m}^{-3}$ and $1.88 \mu \mathrm{g} \mathrm{m}^{-3}$, with a standard deviation of $3.90 \mu \mathrm{g} \mathrm{m}^{-3}$ and $4.45 \mu \mathrm{g} \mathrm{m}^{-3}$, respectively, while the $\mathrm{BC}$ mean concentration was $160.5 \mathrm{ng} \mathrm{m}^{-3}$, with a standard deviation of $296.1 \mathrm{ng} \mathrm{m}^{-3}$, accounting for $10.8 \%$ of $\mathrm{PM}_{1}$ on average.

As expected, the aerosol mass values observed at NCO$\mathrm{P}$ were much lower (at least one order of magnitude) than the corresponding ones measured everywhere else in the Indian Subcontinent: the annual average mass of $\mathrm{PM}_{10}$ was $33 \mu \mathrm{g} \mathrm{m}^{-3}$ (annual average, with similar seasonality as NCOP) in Tirupati, South of India (Chandra Mouli et al., 2006), $74 \mu \mathrm{g} \mathrm{m}^{-3}$ in Agra (Khemani et al., 1982), $66 \mu \mathrm{g} \mathrm{m}^{-3}$ in Ahmedabad (Ganguly et al., 2006) both cities in the IndoGangetic Plain. This reflects the influence of the brown clouds, as well as the larger transcontinental pollution over South and East Asia (Ramanathan, 2001).

The $\mathrm{PM}_{10}$ mean value recorded at NCO-P is comparable with TSP concentrations measured at Nam Co (4730 m a.s.l., Tibetan Plateau) for the period August 2006 to July 2007 showing an annual average of $7 \mu \mathrm{g} \mathrm{m}^{-3}$ and falling in the range $0.5-36 \mu \mathrm{g} \mathrm{m}^{-3}$ (Cong et al., 2009), while in the remote and rural area of Tengchong $(1960 \mathrm{~m}$ a.s.l., Tibetan Plateau), $\mathrm{PM}_{10}$ was measured as $34 \mu \mathrm{g} \mathrm{m}^{-3}$ and $\mathrm{PM}_{2.5}$ as $28 \mu \mathrm{g} \mathrm{m}^{-3}$ (Chan et al., 2006). The aerosol mass values observed at NCO-P are also lower than the European natural background defined by Putaud et al. (2004), within the range $5-10 \mu \mathrm{g} \mathrm{m}^{-3}$.

The BC concentration levels at NCO-P appear very similar to values at Nam Co. For the period when BC measurements are available at both sites (July 2006-January 2007), $\mathrm{BC}$ was on average $82 \pm 70 \mathrm{ng} \mathrm{m}^{-3}$ at Nam Co (Ming at al., 2010) and $91 \pm 113 \mathrm{ng} \mathrm{m}^{-3}$ at NCO-P, suggesting that both stations are representatives of Himalayan background conditions. The monthly mean BC concentration for December 2004, measured at the mountain site of Nainital (Manora Peak, $1950 \mathrm{~m}$ a.s.l., located in the Shivalik ranges of the central Himalayas) was $1.36 \pm 0.99 \mu \mathrm{g} \mathrm{m}^{-3}$ (Pant et al. 2006), thus significantly higher than NCO-P levels for the same season, probably because of the lower altitude and greater vicinity to the strong sources of the Indo-Gangetic plain. In fact, on the Indian plains, BC daily levels range from few $\mu \mathrm{g} \mathrm{m}^{-3}$ up to $27 \mu \mathrm{g} \mathrm{m}^{-3}$ measured in Delhi by Beegum et al. (2009) and Babu et al. (2002). Even on the southern Indian Ocean, $\mathrm{BC}$ concentrations are mostly higher than those observed at NCO-P, especially during winter, testifying to the widely extending atmospheric brown cloud over this area. At NCO-P, monsoon averaged BC values fall mainly in the range of the European continental background, measured between 8 and $104 \mathrm{ng} \mathrm{m}^{-3}$ (monthly median) at Jungfraujoch (Alps, $3450 \mathrm{~m}$ a.s.l.) by Nyeki et al. (1998) and at Monte Cimone (winter average below $100 \mathrm{ng} \mathrm{m}^{-3}$ ) by Marinoni et al. (2008). The NCO-P monsoon values are approximately two orders of magnitude higher than Antarctic background concentrations $\left(\sim 0.65 \mathrm{ng} \mathrm{m}^{-3}\right)$ at the South Pole, one order of magnitude higher with respect to a remote marine boundary location on the island of Mauna Loa $\left(\sim 5.8 \mathrm{ng} \mathrm{m}^{-3}\right)$, and on the same order than the baseline atmospheric station of Barrow, on the northernmost tip of Alaska $\left(\sim 41 \mathrm{ng} \mathrm{m}^{-3}\right)$ (Bodhaine, 1995).

\subsection{Source origin: thermal wind regime versus long range circulation}

As shown by Bonasoni et al. (2010), NCO-P atmospheric compound concentrations are the result of local/regional scale dynamics along the Khumbu valley and long-range transport and synoptic circulation. During the pre-monsoon season in particular, the Khumbu valley is an efficient and persistent channel for transporting large amounts of particles to NCO-P during the day-time up-valley breeze, as also suggested by the analysis of diurnal variations investigated in Sect. 3.1.2. Figure 5 shows the seasonal average $\mathrm{BC}, \mathrm{PM}_{1}$ and $\mathrm{PM}_{1-10}$ split into clusters with respect to wind direction (anabatic or catabatic) and typically clean (night-time) or polluted (afternoon) periods. It is clear that valley breezes play an important role in pollution transport from the low level of Khumbu valley and Himalayan foothills during all seasons (blue bars), while the lowest pollutant concentrations are recorded during mountain breeze conditions (brown and yellow bars). Nevertheless, the effect of seasonality strongly 
(a) PM1

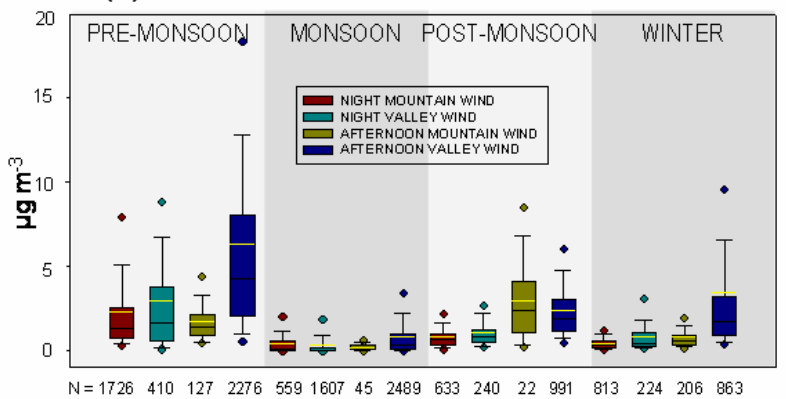

(b) PM1-10

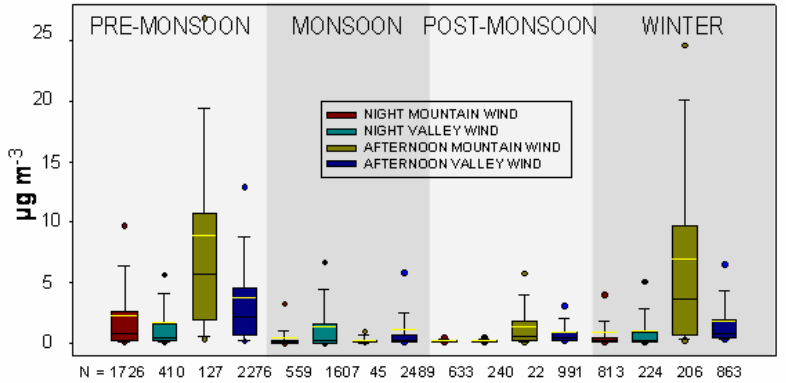

(c) $\mathrm{BC}$

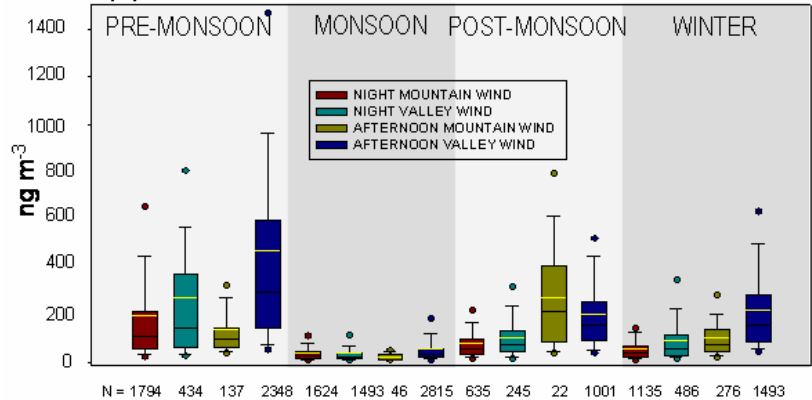

Fig. 5. $\mathrm{PM}_{1}$ (a), $\mathrm{PM}_{1-10}$ (b) and $\mathrm{BC}$ (c) at NCO-P in function of wind direction during nigh-time (00:00-06:00) and during afternoon (12:00-18:00). The numbers reported on the $x$-axis specify the number of averaged 30-min values.

affect the $\mathrm{BC}$ and $\mathrm{PM}_{1}$ concentrations, with pre-monsoon values larger than other seasons. The afternoon concentrations observed under valley wind show same seasonality of the entire data-set, with a peak in the pre-monsoon period, a marked decrease during the monsoon, and "the ramp-up period" in fall and winter, already highlighted by Carrico et al. (2003) in behaviours of $\mathrm{PM}_{2.5}$ both in Langtang (remote Himalayas, $3920 \mathrm{~m}$ a.s.l.) and Nagarkot (a hilltop town on the eastern edge of the Kathmandu Valley, $800 \mathrm{~m}$ a.s.l.). This common seasonal trend reflects the accumulation of mainly anthropogenic aerosols in the Indian Subcontinent in winter and pre-monsoon season. This could be due to the strong emissions in relatively stable and dry atmospheric conditions (Ramanathan et al., 2007), suggesting the influence of brown cloud up to at least the altitude of NCO-P, due to thermal circulation in the valleys.
In Fig. 5, it is interesting to note that pre-monsoon lowest concentrations of $\mathrm{PM}_{1}$ and $\mathrm{BC}$ are associated with mountain winds. This is particularly evident during the afternoon, when the day-time valley winds from South-West are suppressed by synoptic scale forcing, transporting air-masses from North, often characterised by high levels of mineral dust aerosol (Duchi et al., 2010). In fact, as shown in Fig. 5 the largest $\mathrm{PM}_{1-10}$ concentrations (about one order of magnitude larger than the overall average) observed in winter and pre-monsoon season, are associated with mountain wind during the afternoon, suggesting a not-negligible role of mineral dust mobilisation and recirculation from the Tibetan Plateau and Taklimakan desert. However, a significant contribution of $\mathrm{PM}_{1-10}$ is carried to NCO-P by afternoon valley winds, especially in the pre-monsoon seasons, when the Indo-Gangetic Plains are strongly influenced by the transport of dust outbreaks originating in the north-western desert in India (Thar desert, see Gautam et al., 2009), and perhaps even from far off regions (North Africa, see Decesari et al., 2009).

Besides local/regional circulation, synoptic air-mass circulation can also influence the atmospheric composition at NCO-P. To evaluate the possible influence of synoptic-scale air-mass transport on atmospheric composition observed at NCO-P, BC, $\mathrm{PM}_{1}$ and $\mathrm{PM}_{1-10}$ data were analysed as a function of the air-mass cluster classification provided by Bonasoni et al. (2010). In particular, depending on geographical origin and paths of the analysed back-trajectories, seven clusters were identified and classified into three main classes: SW south-westerly (SW-AP: Arabian Peninsula, SW-AS: Arabian Sea, SW-BG: Bengal Gulf); W westerly (W-NA: North Africa, W-EU: Europe, W-ME: Middle East) and REG regional. Following the same methodology presented by Bonasoni et al. (2010), only night time data (00:0006:00) were considered, in order to avoid interaction with air masses carried up with valley winds, and data over the 95th percentile $(6 \mathrm{~h}$ average night-time values) were neglected $\left(5.0 \mu \mathrm{g} \mathrm{m}^{-3}\right.$ for $\mathrm{PM}_{1-10}, 3.4 \mu \mathrm{g} \mathrm{m}^{-3}$ for $\mathrm{PM}_{1}$ and $267 \mu \mathrm{g} \mathrm{m}^{-3}$ for BC) to avoid the influence of outliers.

Figure 6 shows the averaged concentrations of aerosol mass $\left(\mathrm{PM}_{1}\right.$ and $\left.\mathrm{PM}_{1-10}\right)$ and $\mathrm{BC}$ split into the different backtrajectory clusters for each season. Even if seasonality plays an important role in defining atmospheric composition at NCO-P, as is evident looking at scales of the graphs, significant differences are observed within each season between aerosol concentration in air masses of different origin.

During the pre-monsoon season, the largest content of aerosol is associated with westerly air masses from W-ME: such air masses are characterised by a large mineral dust load, together with a high pollution level, and they represents $19.3 \%$ of air masses in this season. To a lesser extent, REG air masses also bring a significant amount of dust and pollution to NCO-P. This cluster represents the second main class of air masses for the pre-monsoon season (23.9\%) and differs from others because of its lower back-trajectory 
$\square$ PM1-10 $\square$ PM1 $\square$ BC

a)

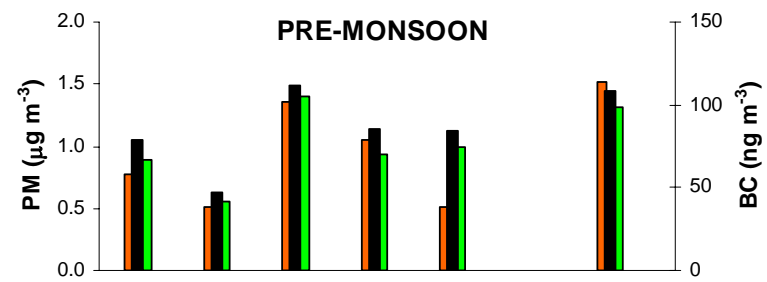

b)

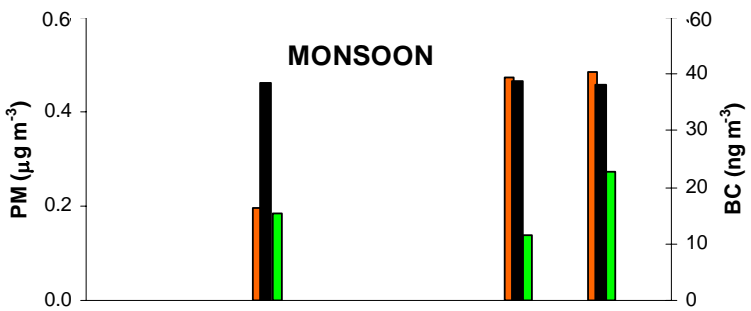

C)

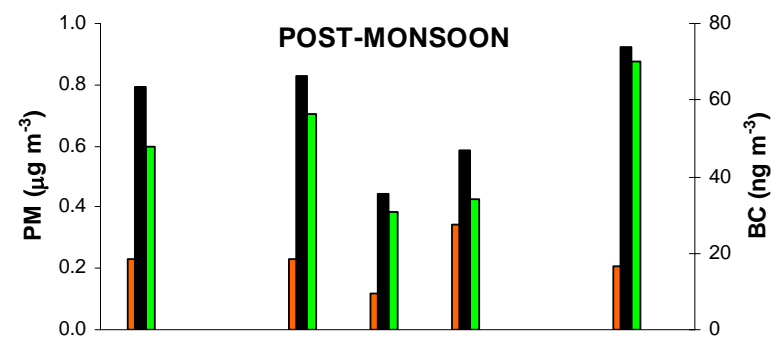

d)

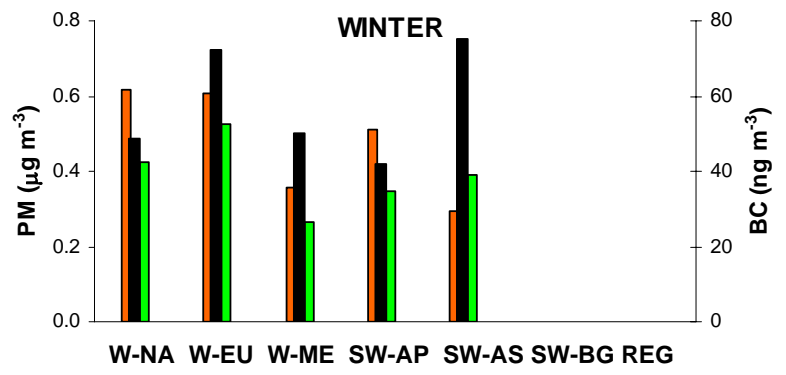

Fig. 6. $\mathrm{PM}_{1}, \mathrm{PM}_{1-10}$ and $\mathrm{BC}$ (average values) classified with different synoptic air mass circulation as defined by Bonasoni et al. (this issue), during (a) pre-monsoon, (b) monsoon, (c) postmonsoon and (d) winter seasons.

altitude, tracing the influence of regional sources (Bonasoni et al., 2010) and explaining the association of dust and pollution. The lower amount of mineral dust is connected to other $\mathrm{W}$ and SW air masses, while pollution shows a minimum with W-EU air masses. A possible role of the Arabian peninsula and Middle-East/Persian Gulf (Lelieveld et al., 2009) as sources of pollution for South Himalayas is suggested by the high fraction of $\mathrm{BC} / \mathrm{PM}_{1}$ from SW-AP and SW-AS .

During the monsoon season, low $\mathrm{BC}$ average values characterised all the analysed air-mass circulation. However, REG and W-ME air masses are associated with the highest amount of $\mathrm{PM}_{1}$ and $\mathrm{BC}$, the highest accumulation mode concentrations were also observed for aerosol size distribution in these air masses (Sellegri et al., 2010). It is important to specify that REG air masses accounted for $73.8 \%$ of air masses in this season, while W-ME accounted for only $3.9 \%$. The SW-BG air masses (20\% of monsoon back-trajectories) brought to NCO-P the cleanest air over the whole year, with only $0.14 \mu \mathrm{g} \mathrm{m}^{-3}$ of $\mathrm{PM}_{1}$ and $38 \mathrm{ng} \mathrm{m}^{-3}$ of BC. In fact, SW air masses are often associated with low pressure over the Gulf of Bengal, causing intense precipitation on the whole Indian Subcontinent up to the Himalayas foothills (Barros and Long, 2003). Only one event from SW-AS (not shown in Fig. 6) brought very high levels of aerosol in concentrations mostly above the seasonal averages $\left(1.7 \mu \mathrm{g} \mathrm{m}^{-3} \mathrm{PM}_{1-10}\right.$, $5.5 \mu \mathrm{g} \mathrm{m}^{-3} \mathrm{PM}_{1}$ and $316 \mathrm{ng} \mathrm{m}^{-3} \mathrm{BC}$ ).

The most frequent post-monsoon back-trajectories (WME: $37.1 \%$, REG: $26.3 \%$ and W-NA: $18.6 \%$ ) were also the most polluted of the season, with high average values of $\mathrm{PM}_{1}$ and $\mathrm{BC}$ but a limited contribution of mineral dust as deduced by the low $\mathrm{PM}_{1-10}$ values. Conversely, SW-AS (7.8\%) airmasses were characterised by the highest content of mineral dust.

During the winter season, the highest $\mathrm{PM}_{1}$ and $\mathrm{BC}$ averaged value was related with W-EU air-masses (frequency: $19.8 \%$ ), for which also relatively high $\mathrm{PM}_{1-10}$ amount were observed at NCO-P. Relatively high pollution levels were traced back to SW-AS air-masses (frequency: $8 \%$ ), while high mineral dust contents were also detected with the most frequent W-NA cluster (frequency: 47.2\%).

The analysis of cluster concentrations and their frequency shows that the long distance air mass transport significantly impacts aerosol concentration and composition: WME and REG air-masses were significantly affected by polluted aerosols from pre-monsoon to post-monsoon seasons, while during winter the highest $\mathrm{BC}$ and $\mathrm{PM}_{1}$ average values were related to W-EU air-masses. Concerning mineral dust, the strongest contributions are mainly from W-ME and REG during pre-monsoon, with possible contributions from SWAS during the post-monsoon and far westerly regions during winter.

\section{Summary and conclusions}

The present paper addresses the diurnal and seasonal variability of aerosol mass and black carbon concentration observed over a two-year period at Nepal Climate ObservatoryPyramid (5079 $\mathrm{m}$ a.s.l.).

The annual mean aerosol mass concentration is $3.8 \pm 8.4 \mu \mathrm{g} \mathrm{m}^{-3}$. The coarse fraction accounts for half of aerosol mass measured by OPC $\left(1.88 \pm 4.45 \mu \mathrm{g} \mathrm{m}^{-3}\right)$, with a larger variability with respect to the accumulation fraction. Black carbon average concentration over two years of measurements is $160.5 \mathrm{ng} \mathrm{m}^{-3}$, with a standard deviation of $296.1 \mathrm{ng} \mathrm{m}^{-3}$.

All the parameters investigated in the paper show a well defined seasonal variation, as well as significant inter-annual variations. The highest concentrations occur during the 
pre-monsoon season, while the minima appear during the monsoon season (prolonged to the post-monsoon period for the coarse mass). The monsoon minimum is attributed to wet scavenging due to frequent cloud and precipitation in this season. The pre-monsoon maximum is linked to an increase of anthropogenic emissions in Indian Subcontinent coupled with the dry meteorological conditions, and to the larger vertical extent of the regional PBL on the Indo-Gangetic plains, associated to the efficient "chimney" effect of the Himalayan valleys.

In fact, $\mathrm{PMs}$ and $\mathrm{BC}$ concentrations show a strong diurnal variation: the daytime maxima of $\mathrm{PM}_{1}$ and $\mathrm{BC}$ are linked to up-valley thermal winds with a maximum in the afternoon, while $\mathrm{PM}_{1-10}$ is linked to wind strength, with a maximum peaked at noon, suggesting a limited contribution from local re-suspension of coarse particles. Night-time mass and BC concentrations are relatively low throughout the year, providing information on free tropospheric background levels at high altitudes in the Himalayas. However, although lower than the daytime values, the night-time levels follow the same seasonality as the diurnal values, suggesting that pollutants reaching the high altitude, pumped by thermal winds or transported by synoptic circulation, can be injected into the free troposphere, where they attain a longer lifetime, and/or accumulate in high residual layers. This is particularly evident in the pre-monsoon season, when the night-time/early morning concentrations remain still high with respect to the rest of the year.

The mean values of PM reported in this study are definitely lower than the Asian and Europe background. However, as shown by the high mean BC values, at NCO-P the nonmonsoon seasons are more affected by regional/continental emissions than European high altitude sites, indicating the influence of the brown cloud up to $5000 \mathrm{~m}$ a.s.l.

The contribution of BC to the total aerosol mass at NCO-P is, on average, higher than 10\% (standard deviation: 9.5\%). The $\mathrm{BC} / \mathrm{PM}_{1}$ ratio shows a maximum contribution of carbonaceous absorbing material to the fine particulate matter during the monsoon season (about $18 \%$ in July-August), while the minimum values characterize the pre-monsoon season (less than 9\% in April-May). Such values are much higher than those measured at other mountain sites, and more similar to the values reported for urban polluted sites. The monsoon maximum can be attributed to a preferential scavenging by monsoon precipitation of the inorganic aerosol fraction with respect to the less hygroscopic black carbon. However, during this season, a possible role of local/regional sources cannot be completely ruled out.

Besides valley breeze regime, synoptic air-mass circulation can also influence the atmospheric composition at NCO$\mathrm{P}$. The analysis of $\mathrm{BC}, \mathrm{PM}_{1}$ and $\mathrm{PM}_{1-10}$ night-time observations as a function of the air-mass cluster classification provided by Bonasoni et al. (2010), confirms that long distance transport of air masses significantly impacts aerosol concentration and composition. Significant differences are observed within each season between aerosol concentration in air masses of different origin/path: polluted aerosols are mainly related to W-ME, REG and W-EU air masses, while the strongest contributions of mineral dust are mainly from W-ME and REG during pre-monsoon and monsoon, with a special contribution from W-AS during post-monsoon and far westerly regions during winter.

Acknowledgements. This work was carried out in the framework of the UNEP-ABC (Atmospheric Brown Clouds) and Ev-K2CNR-SHARE (Stations at High Altitude for Research on the Environment) projects. The contribution of CNRS through the PICS bilateral program between CNR and CNRS and through the LEFE-INSU program is gratefully acknowledged. The authors also thank Tenzing C. Sherpa, Kaji Bista, Laxman Adhikary, Pema Sherpa, Lhakpa T Sherpa, Lakpa T Sherpa, Chhimi T Sherpa and Hari Shrestha for their support at the Nepal Climate Observatory-Pyramid, and Michael Sprenger (ETHZ) for providing LAGRANTO back-trajectories.

Edited by: G. McFiggans

\section{References}

Andreae, M. O., Andreae, T. W., Ferek, R. J., and Raemdonck, H.: Long range transport of soot carbon in the marine atmosphere, Sci. Total Environ., 36, 73-80, 1984.

Andreae, M. O. and Gelencsér, A.: Black carbon or brown carbon? The nature of light-absorbing carbonaceous aerosols, Atmos. Chem. Phys., 6, 3131-3148, doi:10.5194/acp-6-3131-2006, 2006.

Baltensperger, U., Gaggeler, H. W., Jost, D. T., Lugauer, M., Schwikowski, M., Weingartner, E., and Seibert, P.: Aerosol climatology at the high-alpine site Jungfraujoch, Switzerland, J. Geophys. Res., 102, 19707-19715, 1997.

Babu, S. S. and Moorthy, K. K.: Aerosol black carbon over a tropical coastal station in India, Geophys. Res. Lett., 29, 2098, doi:10.1029/2002GL015662, 2002.

Babu, S. S., Satheesh, S. K., and Moorthy, K. K: Aerosol radiative forcing due to enhanced black carbon at an urban site in India, Geophys. Res. Lett., 29, 1880, doi:10.1029/2002GL015826, 2002.

Babu, S. S., Moorthy, K. K., and Satheesh, S. K.: Aerosol black carbon over Arabian Sea during intermonsoon and summer monsoon seasons, Geophys. Res. Lett., 31, L06104, doi:10.1029/2003GL018716, 2004.

Barros, A. P. and Lang, T. J.: Monitoring the Monsoon in the Himalayas: Observations in Central Nepal, June 2001, Mon. Weather Rev., 131, 1408-1427, 2003.

Beegum, G. N., Moorthy, K. K., Babu, S. S., Sathhesh, S., Vinoj, V., Badarinath, K., Safai, P., Devara, P., Singh, S., Vinod, Dumka, U., and Pant, P.: Spatial distribution of aerosol 5 black carbon over India during pre-monsoon season, Atmos. Environ., 43, 1071-1078, 2009.

Bertolani, L., Bollasina, M., and Tartari, G.: Recent biennial variability of meteorological features in the eastern Highland Himalayas, Geophys. Res. Lett., 27, 2185-2188, 2000. 
Bodhaine, B. A.: Aerosol absorption measurements at Barrow, Mauna Loa, and South Pole, J. Geophys. Res., 100, 8967-8975, 1995.

Bonasoni, P., Laj, P., Angelini, F., Arduini, J., Bonafè, U., Calzolari, F., Cristofanelli, P., Decesari, S., Facchini, M. C., Fuzzi, S., Gobbi, G. P., Maione, M., Marinoni, A., Petzold, A., Roccato, F., Reger, J. C., Sellegri, K., Sprenger, M., Venzac, H., Verza, G. P., Villani, P., and Vuillermoz, E.: The ABC-Pyramid Atmospheric Research Observatory in Himalayas for aerosol, ozone and halocarbon measurements, Sci. Total Environ., 391, 241-251, 2008.

Bonasoni, P., Laj, P., Marinoni, A., Sprenger, M., Angelini, F., Arduini, J., Bonafé, U., Calzolari, F., Colombo, T., Decesari, S., Di Biagio, C., di Sarra, A. G., Evangelisti, F., Duchi, R., Facchini, M. C., Fuzzi, S., Gobbi, G. P., Maione, M., Panday, A., Roccato, F., Sellegri, K., Venzac, H., Verza, G. P., Villani, P., Vuillermoz, E., and Cristofanelli, P.: Atmospheric Brown Clouds in the Himalayas: first two years of continuous observations at the Nepal Climate Observatory-Pyramid (5079 m), Atmos. Chem. Phys., 10, 7515-7531, doi:10.5194/acp-10-7515-2010, 2010.

Carrico, C. M., Bergin, M. H., Shrestha, A. B., Dibb, J. E., Gomes, L., and Harris. J. M.: The importance of carbon and mineral dust to seasonal aerosol properties in the Nepal Himalaya, Atmos. Environ., 37, 2811-2824, 2003.

Cachier, H., Buat-Ménard, P., Fontugne, M., and Chesselet, R.: Long- range transport of continentally-derived particulate carbon in the marine atmosphere: Evidence from stable isotope studies, Tellus, 38B, 161-177, 1986.

Chan, C. Y., Wong, K. H., Li, Y. S., Chan, L. Y., and Zheng, X. D.: The effects of Southeast Asia fire activities on tropospheric ozone, trace gases and aerosols at a remote site over Tibetan Plateu of Southwest China, Tellus, 58B, 310-318, 2006.

Chandra Mouli, P., Venkata Mohan, S., and Jayarama Reddy, S.: Chemical composition of atmospheric aerosol $\left(\mathrm{PM}_{10}\right)$ at a semiarid urban site: influence of terrestrial sources, Environ. Monit. Assess., 117, 291-305. 2006.

Cong, Z., Kang, S., Smirnov, A., and Holben, B.: Aerosol optical properties at Nam Co, a remote site in central Tibetan Plateau, Atmos. Res., 92, 42-48, 2009.

Cozic, J., Verheggen, B., Mertes, S., Connolly, P., Bower, K., Petzold, A., Baltensperger, U., and Weingartner, E.: Scavenging of black carbon in mixed phase clouds at the high alpine site Jungfraujoch, Atmos. Chem. Phys., 7, 1797-1807, doi:10.5194/acp-7-1797-2007, 2007.

Chung, S. H. and Seinfeld, J. H.: Climate response of direct radiative forcing of anthropogenic black carbon, J. Geophys. Res., 110, D11102, doi:10.1029/2004JD005441, 2005.

Decesari, S., Facchini, M. C., Carbone, C., et al.: Chemical composition of $\mathrm{PM}_{10}$ and $\mathrm{PM}_{1}$ at the high-altitude Himalayan station Nepal Climate Observatory-Pyramid (NCO-P) (5079 m a.s.1.), Atmos. Chem. Phys., 10, 4583-4596, doi:10.5194/acp-10-45832010, 2009.

Duchi, R., Cristofanelli, P., Marinoni, A., Calzolari, F., Decesari, S., Laj, P., Sprenger, M., Vuillermoz, E., and Bonasoni, P.: Mineral dust transport events at NCO-P (South Himalayas,5079 m a.s.1.), Atmos. Chem. Phys. Discuss., in preparation, 2010.

Forster, P., Ramaswamy, V., Artaxo, P., et al.: Changes in Atmospheric Constituents and in Radiative Forcing, in Climate Change 2007: The Physical Science Basis. Contribution of Working Group I to the Fourth Assessment Report of the Inter- governmental Panel on Climate Change, edited by: Solomon, S., Qin, D., Manning, M., Chen, Z., Marquis, M., Averyt, K. B., Tignor M., Miller, H. L., Cambridge University Press, Cambridge, UK and New York, NY, USA, 2007.

Ganguly, D., Jayaraman, A., Rajesh, T. A., and Gadhavi, H.: Wintertime aerosol properties during foggy and nonfoggy days over urban center Delhi and their implications for shortwave radiative forcing, J. Geophys. Res., 111, D15217, doi:10.1029/2005JD007029, 2006.

Gautam, R., Liu Z,. Singh, R. P., and Hsu, N. C.: Two contrasting dust-dominant periods over India observed from MODIS and CALIPSO, Geophys. Res. Lett., 36, L06813, doi:10.1029/2008GL036967, 2009.

Hansen, J, Lacis, A., Rind, D., Russell, G., Stone, P., Fung, I., Ruedy, R., and Lerner, J.: Climate sensitivity: Analysis of feedback mechanisms, Climate Processes and Climate Sensitivity, Geophys. Monogr. Ser. 29, edited by: Hansen, J. E., and Takahashi, T., AGU, Washington DC, USA, 130-163, 1984.

Hansen, J., Fung, I., Lacis, A., Rind, D., Lebedeff, Ruedy, R., Russell, G., and Stone, P.: Global climate changes as forecast by Goddard Institute for Space Studies three-dimensional model, J. Geophys. Res., 93, 9341-9364, doi:10.1029/88JD00231, 1988.

Henne, S., Klausen, J., Junkermann, W., Kariuki, J. M., Aseyo, J. O., and Buchmann, B.: Representativeness and climatology of carbon monoxide and ozone at the global GAW station Mt. Kenya in equatorial Africa, Atmos. Chem. Phys., 8, 3119-3139, doi:10.5194/acp-8-3119-2008, 2008.

Horvarth, H.: Atmospheric light absorption, Atmos. Environ., 27A, 293-317, 1993.

Hyvärinen, A. P., Lihavainen, H., Komppula, M., Sharma, V. P., Kerminen, V. M., Panwar, T. S., and Viisanen, Y.: Continuous measurements of optical properties of atmospheric aerosols in Mukteshwar, northern India, J. Geophys. Res., 114, D08207, doi:10.1029/2008JD011489, 2009.

Jacobson, M. Z.: Strong radiative heating due to the mixing state of black carbon in atmospheric aerosols, Nature, 409, 695-697, 2001.

Kanakidou, M., Seinfeld, J. H., Pandis, S. N., Barnes, I., Dentener, F. J., Facchini, M. C., Van Dingenen, R., Ervens, B., Nenes, A., Nielsen, C. J., Swietlicki, E., Putaud, J. P., Balkanski, Y., Fuzzi, S., Horth, J., Moortgat, G. K., Winterhalter, R., Myhre, C. E. L., Tsigaridis, K., Vignati, E., Stephanou, E. G., and Wilson, J.: Organic aerosol and global climate modelling: a review, Atmos. Chem. Phys., 5, 1053-1123, doi:10.5194/acp-5-1053-2005, 2005.

Khemani, L. T., Momin, G. A., Naik, M. S., Vijay Kumar, R., and Ramana Murthy, B. H: Chemical composition and size distribution of atmospheric aerosol over Deccan Plateau, India, Tellus, 34, 151-158, 1982.

Krishnan, P. and Kunhikrishnan, P. K.: Temporal variations of ventilation coefficient at a tropical Indian station using UHF wind profiler, Curr. Sci., 86, 447-451, 2004.

Laj, P., Klausen, J., Bilde, M., et al.: Measuring atmospheric composition change. Atmos. Environ., 43, 5351-5414, doi:10.1016/j.atmosenv.2009.08.020, 2009.

Lelieveld, J., Crutzen, P. J., Ramanathan, V., et al.: The Indian Ocean Experiment: Widespread air pollution from south and south east Asia, Science, 291, 1031-1036, 2001.

Lelieveld, J., Hoor, P., Jöockel, P., Pozzer, A., Hadjinicolaou, P., 
Cammas, J.-P., and Beirle, S.: Severe ozone air pollution in the Persian Gulf region, Atmos. Chem. Phys., 9, 1393-1406, doi:10.5194/acp-9-1393-2009, 2009.

Liousse, C., Cachier, H., and Jennings, S. G.: Optical and thermal measurements of black carbon aerosol content in different environments: variation of specific attenuation cross section, sigma, Atmos. Environ., 27A, 1203-1211, 1993.

Marinoni, A., Cristofanelli, P., Calzolari, F., Roccato, F., Bonafe, U. and Bonasoni, P.: Continuous measurements of aerosol physical parameters at the Mt. Cimone GAW Station (2165 m asl, Italy) Sci. Tot. Environ., 391, 241-251, 2008.

Marcq, S., Laj, P., Villani, P., Roger, J. C., Sellegri, K., Bonasoni, P., Marinoni, A., Cristofanelli, P., Vuillermoz, E., Verza, G. P., and Bergin, M.: Aerosol Optical Properties and Radiative Forcing in the High Himalayas Based on Measurements at the Nepal Climate Observatory - Pyramid Site (5079 m a.s.1), 10, 5859-5872, doi:10.5194/acp-10-5859-2010, 2010.

Ming J., Xiao C., Sun J, Kang S. and Bonasoni P., Carbonaceous particles in the atmosphere and precipitation of the Nam Co region, central Tibet, accepted for publication in J. Environ. Sciences, 2010.

Novakov, T., Andreae, M. O., Gabriel, R., Kirchstetter, T. W., Mayol-Bracero, O. L., and Ramanathan, V.: Origin of carbonaceous aerosols over the tropical Indian Ocean: Biomass burning or fossil fuels?, Geophys. Res. Lett., 27, 4061-4064, 2000.

Nyeki, S., Baltensperger, U., Colbeck, I., Jost, D. T., Weingartner, E., and Gäggeler, H. W.: The Jungfraujoch high-alpine research station $(3454 \mathrm{~m})$ as a background clean continental site for the measurement of aerosol parameters, J. Geophys. Res., 103(D6), 6097-6107, 1998.

Pant, P., Hedge, P., Dumka, U. C., Sagar, R., Satheesh, S. K., Moorthy, K. K., Saha, A., and Srivastava, M. K.: Aerosol characteristics at high-altitude location in central Himalayas: Optical properties and radiative forcing, J. Geophys. Res., 111, D17206, doi:10.1029/2005JD006768, 2006.

Petzold, A., Kramer, H., and Schonlinner, M.: Continuous Measurement of Atmospheric Black Carbon Using a Multi-Angle Absorpton Photometer, Environ. Sci. Pollut. Res., 4, 78-82, 2002.

Petzold, A. and Schonlinner, M.: Multi-Angle Absorption Photometry. A New Method for the Measurement of Aerosol Light Absorption and Atmospheric Black Carbon, J. Aerosol Sci., 35, 421-441, 2004.

Pillai, P. A. and Mohankumar K.: Tropospheric biennial oscillation of the Indian summer monsoon with and without the El Nino-Southern Oscillation, Int. J. Climatol., 27, 2095-2101, doi:10.1002/joc.1503, 2007.

Putaud, J.-P., Raes, F., Van Dingenen, R., Bruggemann, E., Facchini, M. C., Decesari, S., Fuzzi, S., Gehrig, R., Huglin, C., Laj, P., Lorbeer, G., Maenhaut, W., Mihalopoulos, N., Muller, K., Querol, X., Rodriguez, S., Schneider, J., Spindler, G,, Ten Brink, H., Torseth, K., and Wiedensohler, A.:A European aerosol phenomenology - 2:chemical characteristics of particulate matter at kerbside, urban, rural and background sites in Europe, Atmos. Environ., 38, 2579-2595, 2004.
Ramanathan, V., Crutzen, P. J., Lelieveld, J., et al.: Indian Ocean Experiment: An integrated analysis of the climate forcing and effects of the great Indo-Asian haze, J. Geophys. Res., 106, 2837128398, 2001.

Ramanathan, V., Li, F., Ramana, M. V., at al.: Atmospheric brown clouds: Hemispherical and regional variations in long-range transport, absorption, and radiative forcing, J. Geophys. Res., 112, D22S21, doi:10.1029/2006JD008124, 2007.

Ruellan, S., Cachier, H., Gaudichet, A., Masclet, P., and Lacaux J. P.: Airborne aerosols over central Africa during the Experiment for Regional Sources and Sinks of Oxidants (EXPRESSO), J. Geophys. Res., 104(D23), 30673-30690, 1999.

Saha, A., Pant, P., Dumka, U. C., Hegde, P., Srivastava, M. K., and Sagar, R.: Aerosol Characteristics at a high-altitude station Nainital during the ISRO-GBP Land Campaign-II. Proceedings of the SRO-GBP Land-Campaign-II meeting, Physical Research Laboratory, Ahmadabad, 1-2 March 2005.

Sellegri, K., Laj, P., Venzac, H., Picard, D., Villani, P., Bonasoni, P., Marinoni, A., Cristofanelli, P., and Vuillermoz, E.: Seasonal variation of aerosol size distribution based on long-term measurements at the high altitude Himalayan site of Nepal Climate Observatory-Pyramid (5079 m), Nepal, submitted, Atmos. Chem. Phys. Discuss., 2010.

Sellegri, K., Laj, P., Marinoni, A., Dupuy, R., Legrand, M., and Preunkert, S.: Contribution of gaseous and particulate species to droplet solute composition at the Puy de Dôme, France, Atmos. Chem. Phys., 3, 1509-1522, doi:10.5194/acp-3-1509-2003, 2003.

Shrestha, A. B.,Wake, C. P., Dibb, J. E., Mayewski, P. A., Whitlow, S. I., Carmichael, G. R., and Ferm, M.: Seasonal variations in aerosol concentrations and compositions in the Nepal Himalaya, Atmos. Environ., 34, 3349-3363, 2000.

Sun, J. and Ariya, P. A.: Atmospheric organic and bio-aerosols as cloud condensation nuclei $(\mathrm{CCN})$ : A review, Atmos. Environ., 40, 795-820, 2006.

Venzac, H., Sellegri, K., Laj, P., Villani, P., Bonasoni, P., Marinoni, A., Cristofanelli, P., Calzolari, F., Fuzzi, S., Decesari, S., Facchini, M.-Cr., Vuillermoz, E., Verza, G.P.: High Frequency New Particle Formation in the Himalayas, PNAS, 105, 41, 1566615671, 2008.

Venzac, H., Sellegri, K., Villani, P., Picard, D., and Laj, P.: Seasonal variation of aerosol size distributions in the free troposphere and residual layer at the puy de Dôme station, France, Atmos. Chem. Phys., 9, 1465-1478, doi:10.5194/acp-9-1465-2009, 2009. 